\title{
METODA DIALOG WARGA (DW) DALAM UPAYA PENINGKATAN RATA-RATA USIA KAWIN PERTAMA PEREMPUAN
}

\author{
Oleh : \\ H. Mulyadi Fadjar, S.Kp., M.Kes.* \\ *Widyaiswara Ahli Muda Bapelkes Provinsi NTB \\ mulyadifadjar930@gmail.com
}

\begin{abstract}
ABSTRAK
Provinsi NTB dengan isu pernikahan usia dini cukup tinggi. Data BPS menunjukan persentase perempuan umur 10-19 tahun pada tahun 2016: 51,19\%, dengan rata-rata usia kawin pertama perempuan masih di bawah target (20,15 tahun) dari target 20,50 tahun. Tujuan program Pendewasan Usia Perkawinan (PUP) adalah memberikan pengertian dan kesadaran kepada remaja agar di dalam merencanakan keluarga, mereka dapat mempertimbangkan berbagai aspek berkaitan dengan kehidupan berkeluarga, kesiapan fisik, mental, emosional, pendidikan, sosial ekonomi serta menentukan jumlah dan jarak kelahiran. Meningkatkan usia kawin perempuan pada umur 21 tahun. Penelitian ini merupakan penelitian kualitatif dengan memberikan gambaran tahapan proses penerapan Metode DW. Sampel dipilih secara acak dengan kriteria merupakan desa dengan kasus perkawinan dini yang tinggi. Tahun 2016, diterapkan pada 10 Desa dan tahun 20017, diterapkan pada 20 Desa pada 10 Kabupaten/Kota Se-NTB. Hasil disajikan secara deskriptif dengan adanya peningkatan rata-rata usia kawin I dari usia 20.15 tahun pada tahun 2016, menjadi usia 20.25 tahun pada tahun 2017
\end{abstract}

Kata Kunci : Metode Dialog Warga, Usia Kawin Pertama

\section{PENDAHULUAN}

Provinsi NTB dengan isu pernikahan usia dini cukup tinggi. Data BPS menunjukan persentase perempuan umur 10-19 tahun pada tahun 2016 : $51,19 \%$, dengan rata-rata usia kawin pertama perempuan masih di bawah target (20,15 tahun) dari target 20,50 tahun. Beberapa faktor penyebab tingginya angka pernikahan usia dini adalah rendahnya pengetahuan dan pemahaman remaja, tentang dampak pernikahan usia dini dan kesehatan reproduksi remaja. pemahaman masyarakat tentang dampak yang akan ditimbulkan, faktor ekonomi keluarga, faktor pendidikan, sosial budaya, pengaruh media dan lingkungan yang menyebabkan terjadinya perubahan sikap dan perilaku remaja.

Menyikapi hal tersebut Pemerintah Provinsi NTB dalam RPJMD tahun 2013-2018 menetapkan Program Pendewasaan Usia Perkawinan sebagai program prioritas. Gubernur Provinsi NTB juga sudah mengeluarkan Surat Edaran Nomor : SE/150/1138/KUM tahun 2014 tentang Pendewasaan Usia Perkawinan.

Tujuan program Pendewasan Usia Perkawinan (PUP) adalah memberikan pengertian dan kesadaran kepada remaja agar di dalam merencanakan keluarga, mereka dapat mempertimbangkan berbagai aspek berkaitan dengan kehidupan berkeluarga, kesiapan fisik, 
mental, emosional, pendidikan, sosial ekonomi serta menentukan jumlah dan jarak kelahiran. Meningkatkan usia kawin perempuan pada umur 21 tahun serta menurunkan kelahiran pertama pada usia ibu di bawah 21 tahun menjadi sekitar 7\% (RPJMD 2010-2014)

Pada saat yang sama para remaja yang merupakan obyek dari isu perkawinan anak membentuk Forum Remaja NTB (For NTB) yang fokus pada pencegahan perkawinan anak. Diharapkan dengan pembekalan bagi penyuluh PUP ini, dapat meningkatkan pemahaman remaja, serta berperan serta secara aktif dalam mengatasi masalah/isu yang ada di masyarakat

"Dialog Warga" mencoba lebih melakukan elaborasi atas kapasitas dan kepentingan komunitas. Asumsi utama adalah bahwa masyarakat telah memiliki pengetahuan maupun pengalaman untuk mengatasi persoalan-persoalan yang menjadi keprihatinan bersama. Tujuan Dialog Warga adalah untuk mengembangkan kompetensi komunitas dalam menangani isu-isu hak asasi perempuan dan kesetaraan laki-laki dan perempuan yang mereka anggap paling penting.

Dari sekian banyak problema yang dihadapi di tengah-tengah masyarakat, yang paling mencemaskan saat ini adalah pernikahan di bawah umur (anak/remaja) yang sangat tinggi. Hal ini terjadi karena berbagai faktor yang saling mempengaruhi antara lain Faktor Pendidikan, Ekonomi, Sosial Budaya, tingkat pengetahuan/ pemahaman masyarakat maupun para remaja tentang dampak negatif dari pernikahan usia dini dan kesehatan reproduksi masih rendah, penerapan pendidikan di dalam keluarga semakin hari semakin berkurang, pengaruh perkembangan teknologi, tingkat pendidikan remaja dan orang tua masih rendah, budaya di sekitar lingkungan yang tidak mendukung, dan kurangnya kontrol/pengawasan melekat (waskat) orang tua kepada anak dalam aktivitasnya.

Asumsi utama adalah bahwa masyarakat telah memiliki pengetahuan maupun pengalaman untuk mengatasi persoalan-persoalan yang menjadi keprihatinan bersama. Tujuan Dialog Warga adalah untuk mengembangkan kompetensi komunitas dalam menangani isu-isu hak asasi perempuan dan kesetaraan laki-laki dan perempuan yang mereka anggap paling penting.

Metode ini di bagi menjadi tiga bagian. Bagian pertama secara sangat ringkas menjelaskan tujuan, prinsipprinsip dasar serta pendekatan dan metode yang menjadi referensi dalam Dialog Warga. Bagian kedua dan ketiga panduan ini memperkenalkan metode fasilitasi dan enam langkah dalam menjalankan Dialog Warga. Para fasilitator pendamping mempunyai peran penting dalam mencapai kesimpulan apakah pendekatan yang diperkenalkan ini dapat diterapkan, mana yang perlu disesuaikan atau sebaiknya ditambahkan. Karena itu, dalam pelaksanaannya sangat padat dengan proses pemantauan, baik ditingkat kelompok sendiri untuk memberi kontrol terhadap perkembangan kegiatan maupun ditingkat fasilitator pendamping untuk menjaga proses aplikasi dan memudahkan pelajaran.

Dalam pelaksanaannya kegiatan Metode Dialog Warga dilengkapi dengan Buku Panduan Fasilitator Desa. Buku panduan ini terdiri dari 3 komponen, yaitu : Komponen 1 : Prinsip Dasar, Komponen 2 : Cara Fasilitasi DW, Komponen 3 : Pelaksanaan DW untuk Penguatan Hak Perempuan

Menyikapi permasalahan tersebut di atas, maka dapat dirumuskan permasalahn sebagai berikut, Bagaimana Metoda Dialog Warga Dalam Upaya Peningkatan Rata-Rata Usia Kawin Pertama. DP3APPKB Provinsi NTB 
sebagai salah Organisasi Pemerintah Daerah yang menjadi leading sektor dalam penanganan perkawinan usia dini, melakukan beberapa kegiatan tentang pendewasaan usia perkawinan dan Kesehatan Reproduksi melalui Seminar, Lokakarya, Rakor, Sosialisasi kepada siswa/siswi SMA/ponpes. Pembentukan kelompok Dialog Warga di masyarakat merupakan kegiatan inovatif dalam metode KIE PUP. Kegiatan ini dimulai Tahun 2015 sebagai pilot project di 1 (satu) Desa yaitu Desa Ubung Kecamatan Jonggat Kabupaten Lombok Tengah. Tahun 2016 dikembangkan di semua Kabupaten/Kota se-NTB dengan Lokasi kegiatan masing-masing 1 (satu) Desa.

Tahun 2017 dikembangkan lagi pada 2 Desa disetiap Kabupaten/Kota seNTB. Untuk mencapai kondisi masyarakat yang paham dan tanggap terhadap persoalan yang kompleks ditengah-tengah masyarakat, terutama masalah kasus perkawinan usia dini dan kekerasan terhadap Perempuan dan Anak serta Keluarga Berencana untuk itu diperlukan tenaga yang terampil sebgaia fasilitator kelompok, maka DP3APPKB Provinsi NTB telah melakukan pelatihan fasilitator Kelompok Dialog Warga di masyarakat pada 10 Kabupaten/Kota se Nusa Tenggara Barat .

\section{METODE}

Jenis penelitian yang digunakan adalah penelitian kualitatif, karena penelitian ini memberikan deskripsi atau gambaran secara sistematis mengenai tahapan proses penerapan Metode DW serta yang berkaitan dengan upaya peningkatan rata-rata usia kawin I perempuan. Penelitian ini dilakukan di 10 Kabupaten/Kota Se-NTB. Tehnik sampling dilakukan secara acak dengan kriteria : Desa dengan kasus perkawinan dini yang tinggi. Metode yang digunakan dalam penelitian ini adalah Metode Penelitian Deskriptif dengan pendekatan Metode Dialog Warga untuk Penguatan Hak Perempuan dan Kesetaraan Gender, dengan pendekatan peningkatan kesadaran masyarakat yang memfokuskan pada kapasitas dan kebutuhan komunitas. Ide untuk Dialog Warga ini muncul karena kenyataan bahwa banyak kampanye tentang hak asasi perempuan atau kesetaraan lakilaki dan perempuan masih bersifat topdown. Kampanye seperti itu meletakkan masyarakat sebagai penerima pasif dari informasi-informasi yang disodorkan kepada mereka. Pendekatan top-down dirasakan baik oleh masyarakat maupun mereka yang melakukan kampanye kurang efektif dan tidak membawa perubahan kesadaran dan perilaku yang lebih responsif terhadap hak-hak perempuan dan kesetaraan laki-laki dan perempuan. Akibatnya, praktik diskriminasi yang dialami perempuan dan ketimpangan relasi antara laki-laki dan perempuan di berbagai bidang kehidupan masih ditemukan di manamana. "Dialog Warga" mencoba lebih melakukan elaborasi atas kapasitas dan kepentingan komunitas.

\section{HASIL DAN PEMBAHASAN}

Tahapan pelaksanaan diawali dengan melakukan Training of Fasilitator (ToF) pada para Fasilitator Provinsi dan Fasilitator Desa Kelompok Dialog Warga Pendewasaan Usia Perkawinan (Kelompok DW-PUP). Fasilitator Desa ditentukan oleh daerah masing-masing dengan pertimbangan dapat berperan serta aktif dalam pelaksanaan kegiatan, 3 orang masingmasing desa (30 orang fasilitator desa). Fasilitator berperan dalam memotivasi warga untuk membentuk Kelompok DW-PUP, melakukan pembinaan, pemantauan dan evaluasi. Kelompok 
DW secara aktif mengidentifikasi potensi, kekurangan dan permasalahan di desa masing-masing. Memberikan penyuluhan dan sosialisasi terkait dengan perkawinan dini, membuat kelompok-kelompok kegiatan remaja untuk meningkatkan aktivitas dan potensi remaja di desa dalam rangka mencegah terjadinyan perkawinan dini, bersama-sama tokoh warga melakukan advokasi dan penyelesaian masalah perkawinan dini yang terjadi di desa, menginisiasi dan memfasilitasi terbentuknya "awig-awig" atau kebijakan lokal sesuai dengan penyebutan atau istilah desa setempat. Awig-awig dapat memberikan legalitas sosial kepada perangkat desa sebagai bahan rujukan utama dalam memberikan solusi dan upaya-upaya penyelesaian masalah perkawinan dini yang terladi di wilayahnya.

Daftar lokasi pembentukan Dialog Warga PUP dimasing-masing Kabupaten/Kota, sebagai berikut:

\begin{tabular}{|c|c|c|c|c|c|}
\hline \multirow{2}{*}{ No } & \multirow{2}{*}{ Kabupaten } & \multicolumn{2}{|r|}{2017} & \multicolumn{2}{|c|}{2016} \\
\hline & & Kecamatan & Desa/Keluarahan & Kecamatan & Desa \\
\hline 1 & Kota Bima & Mpunda & $\begin{array}{l}\text { 1. Kel. Manggemaci } \\
\text { 2. Kel. Mande }\end{array}$ & RasanaeTimur & $\begin{array}{l}\text { Kel. Rabadompu } \\
\text { Timur }\end{array}$ \\
\hline 2 & Bima & $\begin{array}{l}\text { 1. Wawo } \\
\text { 2. Sape }\end{array}$ & $\begin{array}{ll}\text { 1. } & \text { Desa Maria } \\
\text { 2. } & \text { Desa Naru Barat } \\
\end{array}$ & Woha & DesaRenda \\
\hline 3 & Dompu & Dompu & $\begin{array}{ll}\text { 1. } & \text { Desa Mbawi } \\
\text { 2. Kel. Kandaisatu } \\
\end{array}$ & Manggelewa & Nusa Jaya \\
\hline 4 & Sumbawa & Lape & $\begin{array}{l}\text { 1. Desa Labuan Kuris } \\
\text { 2. Desa Hijera } \\
\end{array}$ & Badas & DesaKarang Dima \\
\hline 5 & Sumbawa Barat & PotoTano & $\begin{array}{l}\text { 1. Desa Kokarlian } \\
\text { 2. Desa Senayan } \\
\end{array}$ & Taliwang & BatuPutih \\
\hline 6 & Lombok Timur & Keruak & $\begin{array}{l}\text { 1. Desa Pijot } \\
\text { 2. Batu Putik }\end{array}$ & Montonggading & MontongBetok \\
\hline 7 & Lombok Tengah & Jonggat & $\begin{array}{l}\text { 1. Desa Pengenjek } \\
\text { 2. Desa Batu Tulis } \\
\end{array}$ & Jonggat & \begin{tabular}{|l} 
Ubung \\
Pagutan \\
\end{tabular} \\
\hline 8 & Lombok Barat & $\begin{array}{l}\text { LabuApi } \\
\text { Kediri }\end{array}$ & $\begin{array}{ll}\text { 1. } & \text { Desa Telaga Waru } \\
\text { 2. } & \text { Desa Kediri Selatan } \\
\end{array}$ & Gerung & Sukamakmur \\
\hline 9 & Kota Mataram & $\begin{array}{l}\text { Sekarbela } \\
\text { Ampenan }\end{array}$ & $\begin{array}{l}\text { 1. Kel. Jempong Baru } \\
\text { 2. Kel. Banjar }\end{array}$ & Selaparang & Kel. Monjok \\
\hline 10 & Lombok Utara & Tanjung & $\begin{array}{ll}\text { 1. Desa Teniga } \\
\text { 2. Desa Sokong } \\
\end{array}$ & Bayan & Bayan \\
\hline & REPLIKASI I & W 2017 & & & \\
\hline 1 & Lombok Tengah & Praya & $\begin{array}{l}\text { 1. Desa Mertak Tombok } \\
\text { 2. Desa Sengkerang }\end{array}$ & - & - \\
\hline 2 & Lombok Timur & Sakra & $\begin{array}{l}\text { 1. Swangi } \\
\text { 2. Pandan Wangi }\end{array}$ & & \\
\hline
\end{tabular}

Kelompok DW-PUP yang terbentuk sejak tahun 2014, 1 Desa sebagai pilot roject di desa Ubung Kec. Jonggat adalah 35 Kelompok DW-PUP

Kelompok DW yang dibentuk terdiri dari kelompok Toga, kelompok Toma dan kelompok remaja yang meliputi LSM lokal, remaja putra dan putri. Pembentukan kelompok DW dihadiri langsung dari Dinas PPKB $\mathrm{Kab} /$ Kota dan tim fasilitator provinsi. Dibentuk struktur organisasi kelompok, identifikasi masalah, kekuatan lokal dan dukungan yang ada, khususnya dari Dana Desa yang ada untuk dapat membentuk Kelompok DW-PUP secara mandiri.

Daftar nama organisasi Non Pemerintah yang perperan serta aktif di wilayah masing-masing Kabupaten/Kota

\begin{tabular}{|l|l|l|}
\hline NO & \multicolumn{1}{|c|}{ KABUPATEN/KOTA } & \multicolumn{1}{c|}{ NGO } \\
\hline 1 & MATARAM & KPP NTB \\
\hline 2 & LOMBOK BARAT & KPP NTB \\
\hline 3 & LOMBOK TENGAH & KPI NTB \\
\hline 4 & LOMBOK TIMUR & LPSDM \\
\hline 5 & KABUPATEN LOMBOK UTARA & LPSDM \\
\hline 6 & KABUPATEN SUMBAWA BARAT & KPP NTB \\
\hline 7 & SUMBAWA & LPA / PKBI NTB \\
\hline 8 & DOMPU & LPA \\
\hline 9 & KABUPATEN BIMA & SOLUD \\
\hline 10 & KOTA BIMA & SOLUD \\
\hline
\end{tabular}

Secara umum berdasarkan target dan rata-rata capaian usian kawin pertama perempuan (dalam tahun) di Provinsi NTB : pada tahun 2016 tercapai 20.15 dari target capaian 20.50 dan tahun 2017 tercapai 20.25 dari target capaian 20.75. Kesimpulannya memberikan gambaran, pendekatan Metode DW mampu meningkatkan ratarata usia kawin I dari hasil capaian dari tahun 2016 dan 2017 sebesar 0.15 tahun, walaupun berdasarkan dari target capaian dari tahun 2016 dan 2017 belum tercapai.

\section{PENUTUP}

Kelompok DW-PUP dengan metode DW melibatkan peran serta aktif seluruh komponen masyarakat desa, memberikan motivasi tersendiri dalam upaya untuk mencegah terjadinya perkawinan dini di desanya. Adanya dukungan kebijakan dan dana dari unsur Pemerintah Provinsi, Kabupaten/Kota sampai ke Desa. 
Tetapi masih banyak faktor-faktor penyebab terjadinya perkawinan dini yang perlu ditangani bersama, secara terus-menerus dan berkesinambungan. Pola pikir masyarakat, rendahnya pendidikan dan ekonomi masyarakat, kasus-kasus kehamilan di luar nikah dan perundang-undangan yang tumpang tindih masih merupakan varibel besar sebagai faktor-faktor penyebab terjadinya perkawinan dini.

\section{DAFTAR PUSTAKA}

1. Badan Kependudukan dan Keluarga Berencana Nasional (BKKBN). 2012. Pedoman Pengelolaan Pusat Informasi dan Konseling Remaja dan Mahasiswa (PIK R/M). Jakarta: Direktorat Bina Ketahanan Remaja BKKBN.

2. Buku Saku Pelatihan Pasangan Ramah Anak (PARANA)

3. GTZ-SWR, BP3AKB, Dialog Warga Untuk Penguatan Hak Perempuan dan Kesetaraan Gender: Buku Panduan Bagi Fasilitator Desa, Jakarta, 2011

4. Surat Edaran Gubernur Provinsi NT No.150/1138/KUM tahun 2014, Tentang Pendewasaan Usia Perkawinan 